\title{
3
}

\section{What can policy theory offer busy practitioners? Investigating the Australian experience}

\author{
Trish Mercer ${ }^{1}$
}

\section{Introduction}

When you come into a policy area and don't have the content knowledge, a model can help when you're digesting and making sense of a new area. Compared to an economic framework, it's much more accessible ... Our brains need this type of framework to navigate policy. (Catherine To, interview, 12 February 2019)²

Since leaving the Australian Public Service (APS), and subsequently offering policy training for public servants, I have become curious to explore what insights academic theory could offer on the often confusing, ambiguous and turbulent policy world that I experienced from 1980 to 2010 - having progressed from graduate entry to senior levels without the benefit of any formal training about the policy process! Public servants in Australia tend to learn the craft of policymaking as I did, through immersion in the workplace rather than building on an underpinning

1 Acknowledgements: Adjunct Professor Russell Ayres, Professor Brian Head, Adjunct Professor Wendy Jarvie and Professor John Wanna are thanked for their very helpful comments on earlier drafts. 2 Catherine To was a policy officer in the then Commonwealth Department of Communications and the Arts at the time of her interview. All interviews were conducted by the author. 
academic training. In recent years, more public servants have undertaken formal study (usually at the postgraduate level) or short course training that has introduced them to academic theories of the policy process. Yet, the effect of such exposure to policy theory is an understudied area. This chapter seeks to explore how public servants-practitioners-learn about, and apply, different theoretical models or frameworks in their workplaces.

There are four parts to the chapter. First, I explore how public servants principally learn their jobs 'on-the-job', and how this has begun to change in recent decades. Second, I investigate the world of policy theory and frameworks, concentrating on the different approaches presented in four well-known policy theories and academic debate regarding their merits and limitations. Third, I examine what we know about how practitioners have responded to such frameworks, and what sources of evidence we have as to how they employ these theoretical constructs. The concluding section considers what we have learnt about how policy theory has been put to work to enhance practice and what future appetite there may be to strengthen this theory-practice nexus. My gaze is primarily on public servants at the national level in Australia, but I draw on state and territory examples, and the New Zealand public service where available.

'Policy' is a concept that can evade easy definition. As Wanna, Butcher and Freyens $(2010$, p. 6) remind us, it is 'a live, unfinished endeavour' during both its development and implementation. There is also no agreed term to describe what policy workers do. I concentrate on the bureaucratic skill of being a 'policy adviser', a broad term that goes beyond the sometimes fashionable 'policy analyst' to encompass the policy work involved from policy analysis and advice through to delivery and implementation of adopted policies. ${ }^{3}$

\section{Learning to do policy}

Academics and practitioners concur on how public servants in Australia learn their policy advising skills. In line with the Westminster tradition, these skills (and institutional culture) are acquired primarily through 'craft knowledge' (Rhodes 2016, p. 638). Such craft knowledge is 'something that you learn as you go' (Adams, Colebatch \& Walker 2015, p. 104). In this semi-apprenticeship form of training, seizing practical, experiential

3 This definition is informed by that employed by Lindquist and Tiernan (2011, p. 444) in their investigation of the APS and policy advising. 
opportunities is critical-a chord that resonates in the valedictories and other speeches by current or retiring public service secretaries published by the Institute of Public Administration Australia (IPAA). To cite two recent examples: Andrew Podger (2012, p. 7), a former secretary, had 'serendipitously worked in a series of remarkable teams' in different agencies, while another former secretary, Jane Halton (2016, p. 61), evocatively described how she acquired her policy skills:

I was well-schooled in the craft of the public sector. There was time for this to happen. I was given increasing responsibility, sent to explain very difficult policy to very angry stakeholders on more than one occasion, spent a lot of time working with state governments developing and then implementing new policy. None of this I learnt at university ... People coached me and I was able to make mistakes.

Specific training in policy and the administrative vocation is predominantly learnt once you arrive in the public service, not from what you bring with you, and there is little acknowledgement of underlying value sets and theoretical preconceptions that individuals inevitably hold. At both the national and state levels, the focus has been firmly on 'training for purpose', usually devolved to the individual agency, expressed at the national level through the Australian Public Service Commission's 70:20:10 pedagogic model: 70 per cent from work-based learning, 20 from relationshipbased learning and the remaining 10 from formal education programs (Allen \& Wanna 2016, pp. 23, 28). This has endured at the policy level, as shown by the recent Social policy capability plan developed by the Commonwealth Department of Social Services (DSS) that employed the 70:20:10 standard and described 'experiential learning' (the 70 per cent) as 'the core way' in which policy capacity is developed (DSS 2015, p. 16).

A former senior bureaucrat captured this sense of learning policy as an 'insider':

My observation was, when I was working in the service, [that] there is almost a wish to keep the policy process secret, the notion that it cannot be taught. This is something that you have to be anointed into; it is a different kind of knowledge. (Comment made at an ANZSOG workshop, 9 July 2018)

Indeed, it is still unusual for Australian public servants, unlike their North American or European counterparts, to enter the public service with any formal training in public administration, public policy or political science 
(Di Francesco 2015, pp. 262, 277). Peter Shergold, former secretary of the Department of the Prime Minister and Cabinet (PM\&C), may well have reflected the view of many of his senior colleagues when he described the skill requirements for public policy as 'more in the nature of administrative craft and managerial mystery than political science' (Shergold 2015a, p. $\mathrm{xx}$ ). Following successive waves of public sector reform from the late 1970s, collectively labelled 'new public management' (NPM), economic qualifications together with law and business management have been a high priority in APS recruitments (Crowley \& Head 2015, p. 5). In 2017, for example, economics qualifications were 'by far the dominant pedigree' for APS secretaries, followed by law; only the finance secretary held a degree in political science. ${ }^{4} \mathrm{~A}$ consequence of this experiential focus, as Kate Crowley and Brian Head (2015, p. 15) have observed, is that there is no readily accepted concept of a policy analysis profession in Australia.

This readiness to learn on-the-job and to seize opportunities is congruent with another trait that is seen as characteristically Australian: a well-honed pragmatism (Edwards this volume, Chapter 7). The policy workers David Adams, Hal Colebatch and Christopher Walker interviewed for their study of state public servants described policy in terms of constructing programs of action and consequent negotiation. In one interviewee's words: 'Policy is people trying to work out what they should do about a problem' (Adams, Colebatch \& Walker 2015, p. 103, emphasis added). Pragmatism is also seen as a characteristic of the Australian approach to the public sector reforms that were carried out in the 1980s and 1990s as part of NPM, in contrast to the more sharply theoretical frame initially adopted in New Zealand, for example (Christensen \& Lægreid 2001, pp. 21-2).

\section{Teaching and learning about theory}

\section{Teaching policy skills}

The effects of NPM reforms-such as rapid turnover of staff, emphasis on contract management skills and diversified sources of policy adviceare seen to have created a 'hollow crown' within Westminster public

4 This was the conclusion of Tom Burton (publisher of the Mandarin) in his analysis of a major reshuffle of the 18 portfolio secretaries announced in September 2017 (Burton 2017). My own check of the secretaries' biographies confirms this assessment. 
administrations (Weller, Bakvis \& Rhodes 1997), or at least what Tiernan and Wanna described as a 'discourse of declining policy capacity' (as cited in Tiernan 2011, p. 336). This has created a strong interest in actively rebuilding policy capacity in the APS, and a recognition that, in today's time-pressured and adversarial political environment, an ad hoc apprenticeship model is insufficient to accelerate policy skills development: instead, 'we need to school our people more formally and ensure their ongoing professional development' (Halton 2016, p. 61).

Economic approaches and quantitative skills remain highly valued: an economic perspective is the starting point to much policy development rather than a more broadly based analytical framework. However, in the post-NPM world, there is more recognition of the broader skills that are also required 'to develop and manage policy within increasingly distributed service delivery networks' (Di Francesco 2015, p. 265). With a record of significant underinvestment in staff development (Advisory Group on Reform of Australian Government Administration 2010, pp. viii-ix), the APS has belatedly begun encouraging and supporting staff to undertake postgraduate policy instruction.

Public policy training through postgraduate qualifications such as masters degrees and/or more informal policy training is now widely available, particularly at tertiary level through standalone public policy schools such as the Sir Walter Murdoch School of Public Policy and International Affairs, the University of Melbourne's School of Government, The Australian National University's Crawford School of Public Policy, and, since 2002, the Australia and New Zealand School of Government (ANZSOG). As a bi-national and multi-jurisdictional school dedicated to building executive capacity, ANZSOG offers signature programs such as its Executive Master of Public Administration (EMPA) and the shorter Executive Fellows Program (EFP). Yet, there remains a deep scepticism among Australian public servants about the value of academic learning (and, accordingly, policy theory), reflecting what Hal Colebatch has acknowledged as a 'long-running disconnect between the theory and practice of policy-making' (Adams, Colebatch \& Walker 2015, p. 106; Colebatch, as cited in Mackie 2016, p. 291). This, presumably, at least partly explains what Di Francesco (2015, p. 261) has termed the 'distinctively pragmatic' Australian approach to teaching policy analysis. 


\section{Learning about policy theory}

Broadly speaking, we know that more middle- and senior-level public servants have been exposed in the last two decades to policy concepts and tools (although we have neither quantitative data nor qualitative evidence as to the comparative numbers or impact on practice). Within such policy training and through current public policy texts, practitioners who seek to learn about the policy process discover an extensive theoretical literature, aimed primarily at academics, often requiring deep training to be fully understood, and conveyed in a jargon that is not easily translatable (Cairney 2015, p. 23; Maddison \& Denniss 2009, p. 82).

This literature is also characterised by vigorous, indeed often acrimonious, debate over the limitations of certain theories or models, frequently driven by philosophical differences among academics. These 'duelling analytical frameworks' (Howlett, McConnell \& Perl 2017, p. 65) tend to be seen as contrasting:

- a 'rational-comprehensive' and structured view of the policy world and centralised decision-making (such as a cycle approach), with

- a focus on the myriad of policy actors in a complex policy environment.

Paul Cairney (2015, pp. 26-7) has encapsulated the shift in modern policy theory as the move from an emphasis on top down decisionmaking pursued by a sole central actor to action by many actors (people and organisations) within a complex policy process. While recognising the many hybrid theories, this spectrum is well represented in the four policy theories discussed below. All are North American in origin: in Australasia, we tend to adapt rather than create our own theories. Unfortunately, and perhaps significantly, none address directly the underlying cultural nature of the policy enterprise examined in Chapter 10 by Craig Ritchie. From the plethora of available theories, these four have been selected because they:

- are accessible for practitioners in terms of language employed, explanation of concepts and focus on practical application

- range from normative (i.e. deriving from a standard or norm, especially of behaviour) to empirical, and in emphasis from process-directed to relational (i.e. focusing on multiple actors and organisations)

- have traction in Australia (either with practitioners, academics or both). 


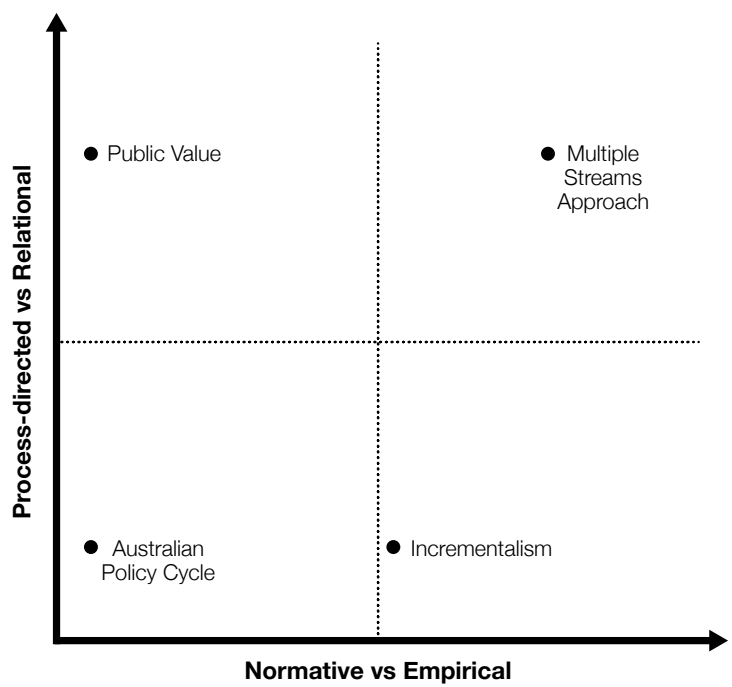

\section{Figure 3.1. Typology of theories investigated.}

Figure 3.1 illustrates where these different theories are situated in terms of the range described above, and Table 3.1 summarises each theory and its intended benefit for practitioners.

Table 3.1. Investigating four major policy theories taught in Australia.

\begin{tabular}{|l|l|}
\hline Theory and brief description & Intended benefit for practitioners \\
\hline $\begin{array}{l}\text { Australian policy cycle: } \\
\text { Policy as a sequence of stages, some } \\
\text { of which may be skipped or repeated; } \\
\text { a logical approach. }\end{array}$ & $\begin{array}{l}\text { Normative: } \\
\text { To offer a practical and comprehensive } \\
\text { understanding of the policy process and } \\
\text { a 'good process' to serve as 'a foundation } \\
\text { for good policy'. }\end{array}$ \\
\hline $\begin{array}{l}\text { Incrementalism: } \\
\text { 'Muddling through'; policymakers tend } \\
\text { to work through consensus and trial and } \\
\text { error rather than through radical change. }\end{array}$ & $\begin{array}{l}\text { Empirical and normative aspects: } \\
\text { development involves small-scale, gradual } \\
\text { modification of existing programs. }\end{array}$ \\
\hline $\begin{array}{l}\text { Multiple streams approach: } \\
\text { Three separate 'streams' (problem, } \\
\text { policy solution and politics) must come } \\
\text { together during a brief 'policy window' } \\
\text { for significant policy change to occur. }\end{array}$ & $\begin{array}{l}\text { Empirical: } \\
\text { To explain how government agendas are } \\
\text { set enabling radical policy change, and how } \\
\text { 'policy entrepreneurs' can influence this by } \\
\text { having policy solutions ready even before } \\
\text { problems emerge. }\end{array}$ \\
\hline $\begin{array}{l}\text { Public value - strategic triangle: } \\
\text { Managers should aim to deliver } \\
\text { 'public value' by managing up and out } \\
\text { ('authorising environment') and down } \\
\text { (operational). }\end{array}$ & $\begin{array}{l}\text { Normative: } \\
\text { To detail what managers 'should think and } \\
\text { do', employing a 'strategic triangle' concept } \\
\text { as a tool for strategy development and } \\
\text { emphasising stakeholder engagement. }\end{array}$ \\
\hline
\end{tabular}


Each of these theories are considered to have strengths and weaknesses. Some of the academic debates swirling around them are discussed in more detail in the chapters by Cairney (Chapter 13) and McConnell (Chapter 14) in this volume. The discussion below seeks to distil the approach and key academic critiques of each theory.

\section{Australian policy cycle: A normative heuristic ${ }^{5}$ to offer a 'good process' guide}

The first is the classic policy cycle, seen as the epitome of the 'rationalcomprehensive' approach and a highly enduring conceptual construct (Howlett, McConnell \& Perl 2017, p. 65). In the 1990s it was adapted for an Australian audience and then published by Peter Bridgman, Glyn Davis and later Catherine Althaus (all with practitioner experience) as the core framework in their textbook, the Australian policy handbook (now in its sixth edition). ${ }^{6}$ Shown in Figure 3.2 below, the Australian policy cycle (APC) is regarded as the cycle's most prominent modern example. The APC follows policy development through eight stages and the authors are quite explicit that 'good policy should include the basic elements of the cycle' (Althaus, Bridgman \& Davis 2018, pp. 2, 45, 49).

The APC has many supporters, especially among practitioners, but has drawn strong academic criticism on the grounds that it is:

- a 'revival of rationalism', idealistic and highly normative (Di Francesco 2015, p. 267; Wanna, Butcher \& Freyens 2010, p. 194)

- lacks agency and is misleading by 'suggesting a more linear and logical progression of policy activities than could be observed in practice' (Paul Sabatier, as cited in Howlett, McConnell \& Perl 2017, p. 69; Maddison \& Denniss 2009, pp. 87-9; Scott \& Baehler 2010, p. 29)

- is not a guide to practice given the complexity of policy and policy actors (Adams, Colebatch \& Walker 2015, p. 108; Colebatch 2006, pp. 1, 26; Gill \& Colebatch 2006, pp. 261-2).

\footnotetext{
5 Heuristic is a term frequently employed in academic theory as both a noun and an adjective; it means to enable a person to discover or learn something for themselves (a 'hands-on' or 'rule of thumb' approach to learning).

6 Originally developed by Bridgman and Davis as a handbook for Queensland public servants, this became a national text in 1998, and Althaus became involved as the third author from the fourth edition. Another well-known example is Eugene Bardach's Eightfold path of policy analysis, based on his Berkeley teaching experience of over 30 years (Althaus, Bridgman \& Davis 2018, pp. 3-4; Bardach 2009).
} 


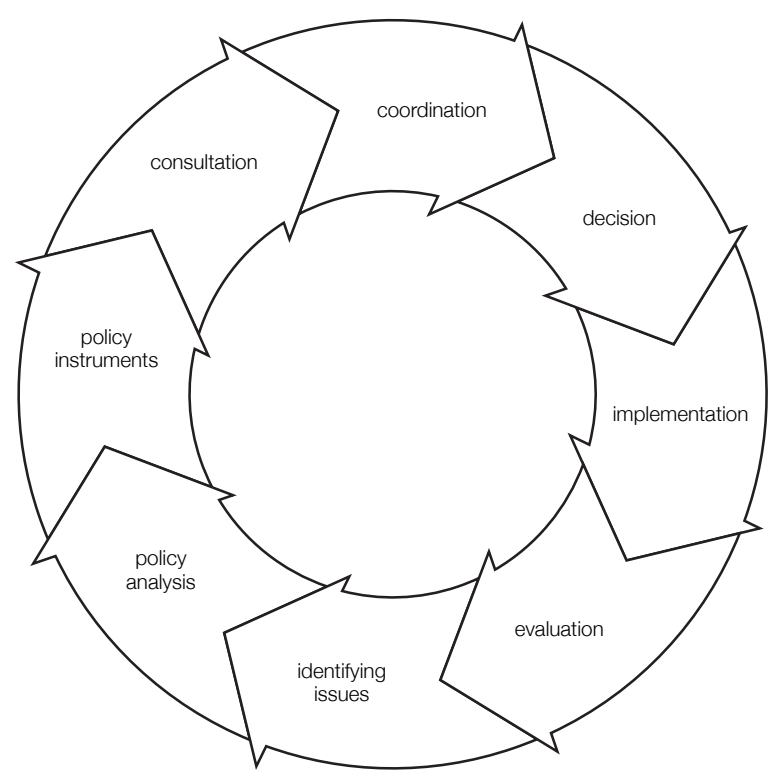

Figure 3.2. The Australian policy cycle.

Source: Althaus, Bridgman and Davis (2018).

Althaus, Bridgman and Davis (2015, p. 112) dispute these criticisms: 'The policy cycle does not assert that policy making is rational, occurs outside politics, or proceeds as a logical sequence rather than as a contest of ideas and interests.' They argue that the critics misinterpret the purpose of the cycle, which is a heuristic that 'can help public servants to develop a policy and guide it through the institutions of government' (Althaus, Bridgman \& Davis 2003, p. 102).

\section{Incrementalism: A realistic but limited behavioural approach}

Incrementalism, or the art of 'muddling through', is the second theory_a behavioural and pragmatic approach developed by the American political scientist Charles Lindblom in the late 1950s and refined over the next two decades as 'disjointed incrementalism'. It was a critique of the rational-comprehensive approach, drawing on Herbert Simon's concept of 'bounded rationality' that recognised the cognitive limitations in information processing and use (Cairney 2015, pp. 27-8). Lindblom argued 
that complex problems can never be fully analysed; therefore, policymakers require incremental analytical strategies 'to make the most of our limited abilities to understand', employing such strategies as:

- a sequence of trials, errors and revised trials

- limiting analysis to only a few policy alternatives

- a greater focus on ills to be remedied than positive goals to be sought (Lindblom 1979, pp. 517, 519).

From an incrementalist perspective, policymakers rarely attempt radical policy change as they choose instead to build on past policies that have been developed through a painstaking process of building consensus among diverse interests. It does not appear to be employed frequently in Australian case studies, although Cockfield and Botterill (2013, pp. 138-9), in their study of rural and regional policy, concluded that such policy over the last 50 years was a story of 'punctuated incrementalism'.

Incrementalism, as the Australian policy handbook recognises, 'probably most accurately describes how policy making proceeds', given that it builds on bureaucratic expertise and familiarity with programs (Althaus, Bridgman \& Davis 2018, p. 95). Among the criticisms levelled at such a 'small steps' incremental approach are that it encourages conservatism, inertia and the adoption of risk-averse approaches (Althaus, Bridgman $\&$ Davis 2018, p. 95; Wanna, Butcher \& Freyens 2010, pp. 195-6). John Kingdon (2011, p. 80) has argued that such an approach does not account for how agendas can change suddenly and that significant problems facing governments may require more radical interventions. Incrementalism lost support (as a normative prescription, if not as an empirical description) during the NPM reforms and in the turbulent economic and political environment of recent years (Wanna, Butcher \& Freyens 2010, p. 196).

\section{Multiple streams approach: An explanation for agenda-setting}

One of the acknowledged limitations of the policy cycle is that it does not seek to generate causal explanations for how policy develops (Althaus, Bridgman \& Davis 2018, p. 47). Explaining the puzzle of how and why 'an idea's time has come' was taken up by Kingdon in 1984 through his multiple streams approach (MSA), which focuses specifically on how agendas are set, using the metaphor of three independent streams: 
- problem-attention lurches to a policy problem

- policy-a solution to the problem is available

- politics-policymakers have the motive and opportunity to turn a solution into policy (Cairney \& Jones 2016, p. 40).

These streams come (flow) together and become coupled at critical junctures, which Kingdon (2011, pp. 78, 165) depicted as a 'policy window' opening in the political system, enabling a marked, even radical change in policy. ${ }^{7}$ MSA thus offers a counterintuitive strategy for policy advisers - for example, by producing solutions before chasing problems, because there will be no time to produce a solution when a policy window (briefly) opens. 'Policy entrepreneurs' who display qualities such as persistence can employ a policy window to secure government attention, but are dependent on the environment being right, like 'surfers waiting for the big wave':

Advocates lie in wait within and around government with their solutions at hand, waiting for problems to float by to which they can attach their solutions, waiting for a development in the political stream they can use to their advantage ... Sometimes, the window opens quite predictably ... At other times, it happens quite unpredictably. (Kingdon 2011, p. 165)

MSA draws on Cohen, March and Olsen's (1972) 'garbage can' model of policymaking and seeks to capture the complexity, ambiguity and occasional chaos in policy episodes (as cited in Colebatch 2006, p. 14; Kingdon 2011, p. 78). As a flexible approach, it has a big fan club within academia globally, and has influenced policy theory and been employed in numerous case studies (Cairney \& Jones 2016, pp. 43, 45, 49). Howlett, for example, in employing MSA in a Canadian context, found that routine policy windows, such as elections, arose more frequently than other more random opportunities (as cited in Cairney \& Jones 2016, p. 48).

However, MSA has also been criticised on a number of fronts, including:

- it was distilled by Kingdon from observing deliberations of the United States Congress; therefore, its applicability for Westminster systems is questionable (although it is also argued that, by being built on the highly abstract 'garbage can model', its insights extend beyond the original focus of study) (Cairney \& Jones 2016, p. 38)

7 Kingdon (2011, p. 3) defines the 'agenda' as 'the list of subjects or problems to which governmental officials, and people outside of government closely associated with those officials, are paying some serious attention at any given time'. 
- it offers the flexibility and ability to inspire empirical studies; however, the number of studies in which Kingdon is cited superficially is 'more than troubling' (Cairney \& Jones 2016, pp. 38, 51-2)

- it may be tautological when used to provide post-hoc explanations

- it would require substantive stretching 'to move from agenda-setting activity to encompass the entire policy process' (Howlett, McConnell \& Perl 2017, p. 71).

\section{Public value: Aspirational and normative heuristic aimed at individual managers}

The fourth policy theory was created by Mark Moore, a Harvard Kennedy School of Government professor (Creating public value: Strategic management in government 1995; Recognizing public value 2013). Public value is seen as a post-NPM paradigm, offering a model of management in an era of 'networked governance' (Stoker, as cited in Alford \& O'Flynn 2009, p. 179). Rhodes and Wanna (2009, p. 180) —strong critics of public value-see its attraction as due to the 'high esteem' attributed to the public sector, with middle to senior public servants responding to this acknowledgement of their contribution following years of top down NPM reforms. The following example gives a sense of this valueoriented perspective, and of how public value has entered into the language of practitioners. Andrew Nicholls, a New South Wales public servant and EMPA graduate who received a Public Service Medal in the 2018 Australia Day honours list, described what motivated him: 'I have a strong commitment to the ethic of public service and I've always been attracted to the roles which focus on generating public value not private value' (ANZSOG 2018, emphasis added). Moore's approach, created specifically for public sector managers, was developed as a normative theory of managerial (rather than organisational) behaviour: 'it details what managers should think and do' (Moore 1995, p. 2, original emphasis). The core idea in public value theory is the 'strategic triangle', represented in Figure 3.3. 


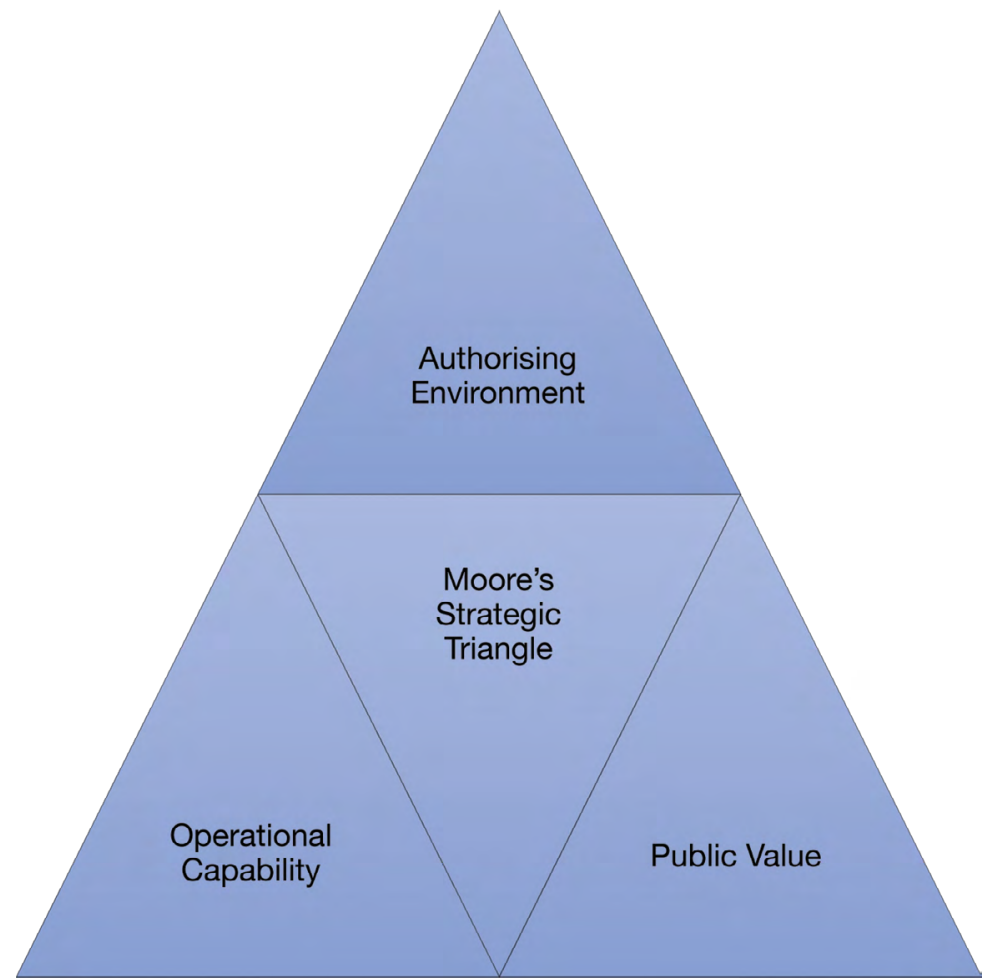

\section{Figure 3.3. Moore's strategic triangle.}

Source: Louise Gilding (Chapter 11, this volume), based on Moore (1995).

Public value: managers need to develop 'public value propositions' for their agencies/ areas/programs, akin to a 'business case', but also drawing in the public's aspirations and concerns.

Authorising environment (legitimacy and support): managers need to 'manage up' and 'manage out' by actively gathering legitimacy and support for their value propositions from their political leaders and also many other actors (such as parliament, interest groups, media, clients).

Operational capabilities: managers need also to 'manage down' to ensure that there would be the requisite resources, people and processes for the task.

(Alford et al. 2017, pp. 590-1)

Public value has been influential among senior public servants in Australia and New Zealand and, to a lesser extent, in the UK (Di Francesco 2015, p. 267; Rhodes \& Wanna 2009, p. 161). A major contributing factor has been its centrality in public management courses in Australasia, particularly in ANZSOG's EMPA and EFP in the last 15 years, which included personal presentations by Moore until recent years (Alford et al. 2017, p. 592; Scott \& Baehler 2010, p. 15). Moore has also presented in ANZSOG chief executive officer forums. 
In Australia and New Zealand, public value has drawn much greater interest from public management academics and business schools than from those in public policy (Alford et al. 2017, p. 592; Bryson, Crosby $\&$ Bloomberg 2014, p. 452). Public policy texts in Australia tend to ignore public value (Colebatch 2006; Maddison \& Denniss 2009) or criticise it (Wanna, Butcher \& Freyens 2010, pp. 41-4). Two exceptions are short discussions in the Australian policy handbook (Althaus, Bridgman \& Davis 2013, p. 34, 2018, p. 13) and longer coverage in a textbook written by Scott and Baehler (2010, pp. 15-17), two New Zealand academics who taught in the early ANZSOG programs.

As with the policy cycle, public value has prompted robust academic debate-in particular, between two public policy academics, Rod Rhodes and John Wanna, who argued that it is not appropriate for Westminster systems of government, and public value supporters (and ANZSOG teachers) such as John Alford and Janine O'Flynn, who came to Moore's defence (Alford 2008; Alford \& O’Flynn 2009; Rhodes \& Wanna 2007, 2008, 2009). One consequence has been more theoretical work by Moore, Benington and others to clarify definitions and terms: for example, 'public value' is characterised as 'a broad portmanteau phrase expressing ideals and aspirations about public service, but capable of meaning many different things to different people' (Benington 2009, p. 233; Bryson, Crosby \& Bloomberg 2014, pp. 453-4). In July 2019, a number of public policy academics came together at the University of Queensland, Brisbane, to workshop the concept of public value and its theoretical and practical application: participants were generally agreed that public value has wide application, but as a concept it is messy' (Brown et al. 2019, p. 22).

While these four theories are all intended for practical application, their views on policy are quite sharply differentiated. The APC seeks to guide public servants-particularly the inexperienced — through policy development processes within a centralised Westminster system of government. By contrast, incrementalism presents policy development as one of gradual evolution whereby public servants seek to achieve change through small steps; the emphasis is on incremental analytical strategies to progress policy action. The other two theories place greater emphasis on complexity and multiple actors. Under MSA, the intersection of three independent streams (problem, policy and politics) can explain how a policy window opens to enable a significant policy change. The 
public value approach, with its key concept of a strategic triangle, was constructed by Moore as a tool to guide managers in determining what they should think and do within their own policy environments.

\section{Applying theory to practice}

Given the dominant vein of pragmatism among public servants, and the equally strong vein of scepticism of academic discourse, it could be expected that academic theories of the policy process would not meet with a receptive audience. Yet, in their admittedly small survey of how state public servants learnt about policy work, Adams, Colebatch and Walker (2015, p. 105) found that those who had taken up study after several years on-the-job found a significant benefit, as articulated by one of their respondents:

What interested me ... I was trying to get a better understanding of what the heck I'd been doing for the last 20 years because

I didn't have a vocabulary or a framework to explain it.

As we have also seen with public value, practitioners can display enthusiasm and interest, at least when such theory is offered in an interactive setting such as ANZSOG's EMPA and EFP.

In terms of policy process theory, the four approaches examined here were all intended to 'speak' to policy advisers, with language and imagery that could be understood relatively easily - and readily recalled. Based on the literature and practitioner feedback, the following section explores what we know about how public servants have accessed and responded to such policy theory.

\section{Australian policy cycle: Impact}

With cumulative sales of over 30,000 and now in its sixth edition, the Australian policy handbook has become a 'staple' for undergraduate policy subjects and required reading for graduate courses (Althaus, Bridgman \& Davis 2018, p. 4; Di Francesco 2015, p. 267). One of its authors (Bridgman) has, for many years, delivered two-day policy workshops in capital cities (Brisbane, Canberra and Sydney), with participants receiving 
a copy of the handbook. ${ }^{8}$ The APC's success has been attributed to its practical approach, simplicity, comprehensiveness and 'analytical scope and range' (Howlett, McConnell \& Perl 2017, p. 66; Scott \& Baehler 2010, p. 34).

\section{Using the cycle as a guide for policy action}

The APC's value as a practical guide is explored by two pracademics ${ }^{9}$ in this monograph:

- Meredith Edwards (2001, p. 4), who employed the APC in her case study of major social policy reforms, reflects in Chapter 7 (this volume) on its use as a heuristic for practice-'a valuable, if rough guide to action in pursuing success for a policy position'

- Russell Ayres in Chapter 8 (this volume) relates how he adapted the APC, with tweaks for complexity, in 'under the radar' information sessions with his own staff on the theory of policymaking.

The cycle approach has many supporters. Gary Banks, former dean of ANZSOG and former head of the Commonwealth's Productivity Commission, has recently stated that the policy cycle, notwithstanding critiques of its sequential aspects and rationalist conception of policymaking, remains a useful 'good process' test in the way its components match up with standard requirements in the policy process. He employed a small number of 'good process' indicators to assess (not favourably!) recent government policy initiatives such as the National Broadband Network and emissions trading scheme (Banks 2018).

Given that the policy cycle sits naturally with an emphasis on centralised decision-making, it is not surprising that examples located within institutional frameworks of policy processes tend to draw on the cycle as their organising construct:

- Andrew Maurer in Chapter 12 (this volume) demonstrates this affinity in his exploration of how he developed a policy handbook for his department (Communication and the Arts).

8 Bridgman is a former practitioner in the Queensland public service and delivers these workshops with another ex-practitioner. Their website provides course details and feedback from participants (see policyskills.com.au).

9 A pracademic (or practitioner academic), while not appearing in dictionaries, is a term that has been in use for some 30 years and is defined as someone who is both an academic and a practitioner in their subject area. 
- Another example can be taken from the DSS's Social policy capability plan, which described understanding the policy cycle as a characteristic of capable social policy officers (DSS 2015, p. 3).

An exception to this use of the cycle in institutional frameworks is a policy development toolkit developed for staff in the then Commonwealth Department of Industry, Innovation and Science in 2014, and placed on their intranet site. The toolkit provides an introduction to the fundamentals of policymaking and pointedly offers a 'realistic policy model' that presents policy as an iterative and adaptive process rather than a logical progression of separate and distinct steps (Department of Industry, Innovation and Science 2014, pp. 3, 13).

Beyond Australasia, Cairney (2015, p. 26) notes that UK departments, such as the Cabinet Office, have maintained versions of the policy cycle model of policymaking. The World Bank (2019) also employs a project cycle approach that has similar stages to the policy cycle, although this may involve multiple overlapping cycles that emphasise the complexity of their processes.

As a normative model, the policy cycle implies a prescription for a rationalcomprehensive plan of action that aligns with the centralised decisionmaking seen as integral to Westminster systems and democratic politics. A staged approach to policymaking is deeply embedded in public service practice. A policy proposal being put forward to Cabinet, for instance, needs to be able to be presented, discussed and recorded as having undergone careful consideration of the issue or problem, the options available to government, the views of key stakeholders and the likely consequences of any decision taken; that is, a proposal that has encompassed all the dimensions of policy development envisaged in the cycle, even where the actual process in all likelihood will not have followed such a 'rational' path! In Chapter 13 (this volume), Cairney discusses the 'far messier reality' of policymaking compared to this projection of centralised policy made through orderly stages. He argues that perhaps the most we can expect of the policy cycle's stages is 'to treat them as a checklist of functions to carry out at some point'; in other words, not applying them rigidly or in order, and with an appreciation of the bigger picture. 


\section{Incrementalism: Impact}

The incrementalist explanation of policy development emphasises that we can only ever have imperfect knowledge; therefore, we need strategies for 'skillful incompleteness' (Lindblom 1979, p. 524). Lindblom's emphasis on building from existing policy understandings and arrangements is likely to feel intuitively familiar for public servants, especially those involved in implementation. Moreover, the APC's authors have noted that, when exercising judgement about how much time and thought to devote to a problem, agreement based on the 'quick and rough calculations of incrementalism' may be 'the most effective way to proceed' (Althaus, Bridgman \& Davis 2018, p. 95). Lindblom (1979, p. 520) argues that it is also possible to achieve rapid and significant change under incrementalism, precisely because, by their very nature, such changes 'do not rock the boat, do not stir up the great antagonisms and paralyzing schisms as do proposals for more drastic change'.

An element of Lindblom's work that continues to resonate is his emphasis on a 'trial and error' strategy. Shergold's (2015b, pp. 6-7) report for the Abbott Coalition government in 2015 on Learning from failure recommended such a 'learning by doing' strategy for Commonwealth public servants, involving testing out ideas on a small-scale, trialling different delivery options and making rapid adjustments as necessary.

Cairney (2015, p. 31), drawing on his conversations with UK civil servants in policy training seminars, suggested that incrementalism, with its familiar, practical qualities, 'translates well' from theory to practice. There is no direct Australian evidence, but the story here may be similar. Certainly the feedback from public servants in policy workshops that I have conducted has been that incrementalism is immediately familiar to them, and many have indicated that this best describes their current work environment. ${ }^{10}$ Indeed, the former secretary of the Department of Foreign Affairs and Trade, Peter Varghese (2016, p. 35), made a personal plea for what he termed 'radical incrementalism':

If I were to give one piece of advice to the next generation of public service leaders it would be to advocate the virtues of radical incrementalism ... The only sustainable change is change that is

10 With Adjunct Professor Wendy Jarvie, I have jointly offered workshops on 'policy essentials' through the ANU Crawford School of Public Policy Executive Education program, which includes a session exploring the insights from key policy process theories such as incrementalism. 
understood and then accepted ... And that takes persuasion and vision and the hard yards of incremental improvements in pursuit of a bigger agenda.

However, one of the newer secretaries, Heather $\operatorname{Smith}^{11}$ (2018, p. 40), then head of the Department of Industry, Innovation and Science, questioned whether, because these are 'not ordinary times', such radical incrementalism 'will now get us to where we need to be'.

In making these claims, it is unlikely that these senior bureaucrats were systematically drawing on academic theory. Nevertheless, for many public servants who have studied policy theory, incrementalism may appear as a status quo option-too passive in a policy world beset by 'wicked' problems requiring multidimensional responses ${ }^{12}$ - even while it may continue to be an accurate description of how a significant body of policy work is quietly achieved, particularly in Commonwealth-state contexts.

\section{Multiple streams approach: Impact}

While many public servants may not recognise that they are drawing on Kingdon's work, his evocative descriptions of the policy process have been taken into the policy vocabulary: notably, 'policy window' and 'policy entrepreneurs'. MSA's coverage in major textbooks and the number of Australian case studies employing the approach indicate its influence among academics (Althaus, Bridgman \& Davis 2018, p. 47; Colebatch 2006, p. 14; Fawcett et al. 2018; Lancaster et al. 2017: Rodwell 2016). Two examples from individuals who have bridged the academic and policy worlds are illustrative. First, the doctoral study by Kathleen Mackie (which she draws on in Chapter 9, this volume) examined 30 years of environmental policy development by bureaucrats in the Commonwealth department (in which she had been a senior executive). An unexpected finding from her extensive interviews with policy officers was the, at times, covert role adopted to pursue success and avoid failure, which she found:

11 Heather Smith lost her position under Prime Minister Morrison's restructure of the APS in December 2019.

12 Alford and Head (2017) have investigated how 'wicked' has become an inflated and overused term that obscures distinctions between different forms of problems. 
More akin to the kind of agency found in Kingdon's (1984) exploration of the role of policy entrepreneurs to determine why issues did or did not get on to the US government's policy agenda. (Mackie 2016, p. 300)

Second, Edwards, who adopted a modified policy cycle in her study of major social policy, also dipped briefly into MSA when she compared the behaviour of a group of DSS officials during the internal development of the Keating government's Working Nation initiative to Kingdon's 'entrepreneurs':

The group of DSS officials who had been working on a particular set of policies for some years found the right angle and right timing to have a significant influence on the income support policies contained in Working Nation. (Edwards 2001, p. 188)

Intriguingly, no specific examples of MSA being employed by current practitioners have yet come to light. While its concepts are vivid and readily explained, it may not be frequently taught in formal or informal public policy training. ${ }^{13}$ Moreover, MSA does not offer a clear template for practical application and there is a risk that it could be backwards fitted by practitioners wishing to make a messy process of policy development seem more coherent. Yet, Kingdon's concept of being ready for a policy window to open is a strategy that policymakers may understand instinctively; consequently, they may be drawn to his counterintuitive strategy of developing solutions in advance of problems emerging.

\section{Public value: Impact}

Notwithstanding academic critiques, senior public servants in Australia and New Zealand have responded with interest and enthusiasm to public value and, specifically, to the heuristic tool of the strategic triangle (Alford et al. 2017, p. 592; Alford \& O’Flynn 2009, pp. 171-2; Prebble 2012, p. 392). The 2018 edition of the Australian policy handbook somewhat diplomatically noted that 'traction between public value ideas, theorists

13 Discovering this would require a survey of the various institutions offering public policy courses. I am aware of two examples: 1) Brian Head (University of Queensland) has drawn on MSA for a masters course on policy analysis; 2) Paul Fawcett (now at the University of Melbourne) has employed this framework in policy training, including with policy officers from the then Commonwealth Department of Communications and the Arts, and he believes that public servants can get a handle on this theory relatively quickly and intuitively (Brian Head, personal communication, 23 June 2019; Paul Fawcett, personal communication, 5 July 2018). 
and practitioners is strong' (Althaus, Bridgman \& Davis 2018, p. 13). More directly, Di Francesco (2015, p. 268, original emphasis) commented that 'the nub of the dispute [about public value] is that practitioners find the concept useful'. A recent academic workshop on public value agreed that this was 'a term created by academics and then adopted by public managers' to describe their work (Brown et al. 2019, p. 21). The term 'public value' is frequently employed in public policy discussions, not only at bureaucratic and academic levels, but also, occasionally, at political levels (Alpers \& Ghazman 2019, p. 211; Australian Government 2019, p. 1; Gallop 2018; Tiernan 2011, p. 343). For public managers, the public value approach offers recognition of their ability to influence policy and decisions and encompasses earlier respected concepts such as the public interest and the common good (Bryson, Crosby \& Bloomberg 2014, pp. 449-51).

In academic circles, the current status of public value management has been described as 'mainly heuristic' (Althaus, Bridgman \& Davis 2018, p. 13; Brown et al. 2019, p. 9; Hartley et al. 2017, pp. 670-1) ${ }^{14}$ given the lack of empirical studies of this approach in action. Therefore, there is no strong body of evidence to demonstrate its strengths and weaknesses, including whether public managers are being careful to balance discretion and responsiveness in any coalition-building, as Rhodes and Wanna (2008, p. 368) urged.

Nevertheless, examples have not been difficult to find as to how practitioners have adapted the public value framework of the strategic triangle to their particular environment and circumstances. In IPAA and ANZSOG forums, and in presentations at public policy conferences and workshops, senior bureaucrats have publicly referenced the strategic triangle and its 'authorising environment' concept, presumably expecting that at least some of their audience will make a connection. ${ }^{15}$ Senior public servants have also shared how they have adapted Moore's framework. Duncan McIntyre, a division head in the then Commonwealth Department of Industry, Innovation and Science who was in the first EMPA cohort,

14 To my knowledge, the only Australian study of implementing public value management is by Edwards, Soo and Greckhamer (2016, p. 188). Their case study of disability sector reform in Western Australia concluded that public value approaches had enabled the development of community networks and the trialling of co-created innovations.

15 Two examples of events in Canberra at which current or past senior executives employed Moore's concepts were hosted by the IPAA: 'Future leaders', 22 November 2018, and 'Prioritising reform', 18 September 2019. 
amended the strategic triangle's descriptors as the language failed to resonate with his staff. He used the following questions to talk his people through the concept of public value and strategy development:

- What should we do (to achieve public value)?

- What can we do (the organisation's capacity)?

- What are we allowed to do (by the political layer)?

In McIntyre's (personal communication, 22 March 2018) experience, most people know more about the first question, which means that more attention needs to be focused on the last two.

Louise Gilding, an EMPA graduate and senior executive in the ACT Government, explains in Chapter 11 (this volume) how she developed a 'blended approach' to employ with her team, involving the use of four questions and the strategic triangle. Her framework is a kind of hybrid, in that it begins with the early stages of the policy cycle (such as identifying and analysing the problem) before incorporating a public value approach by asking if it will 'make a difference', achieve support and be implementable. Moreover, as Gilding notes, her framework is flexible: 'scalable across problems, timeframes and resources'.

Employment of the public value approach is not restricted to ANZSOG graduates. Catherine To, the policy officer quoted at the start of this chapter, considered that the unit on public value in her masters degree in communications from Griffith University provided her with a reflective tool: 'I use Mark Moore's strategic triangle as a means of stepping backas a kind of template, how should I address this issue' (Catherine To, interview, 12 February 2019).

\section{What can we learn about taking policy theory into practice?}

This exploration of the response to four well-known policy theories has indicated that, in these early decades of the new century, public servants, albeit at an individual level, are receptive towards policy theory offerings. Their knowledge appears to have been principally acquired through short or longer-term policy training offered by universities or other training institutions specialising in executive education, and probably reinforced 
at times by short pieces in grey literature now available in online public policy sites such as the Mandarin, Per Capita, the Conversation, and Analysis and Policy Observatory. ${ }^{16}$

The policy vocabulary employed by many practitioners now contains some of these academic concepts, which are sometimes jarring in an Australian context-for example, muddling through, policy window, policy entrepreneur and, above all, authorising environment. At a recent IPAA event in Canberra, the keynote speaker (head of a prominent think tank), a panel member (former head of department in both Commonwealth and state arenas) and audience member (head of a statutory agency) engaged in an animated conversation drawing on Moore's framework and authorising environment concept to discuss the contemporary difficulties of prosecuting policy reform (IPAA 2019). At an institutional level, however, there appears to be an implicit and longstanding bias towards a cycle or stages approach for depicting policy development, not only for its coverage of policy from start to finish, but also, perhaps, for its utility 'to help ministers project a sense of central control' (Cairney this volume, Chapter 13).

Among ANZSOG graduates, the public value theory has caught the imagination of senior public servants at both Commonwealth and state levels and in policy and delivery roles. This underlines the medium of interactive discussions as a conduit for offering policy theory in an accessible way, as Cairney (2015, p. 33) also emphasises, based on his experience of offering policy training to UK civil servants: 'It is the discussions, beginning with limitations of cycles and exploring policy theory alternatives, that make the difference, not the reading materials.'

Possibly the strong focus on public value offered in ANZSOG's EMPA and EFP has avoided the risk of participants drowning in a sea of academic theory and debates. Direct academic (or pracademic) engagement can certainly help with the translation of theory, as reflected in a participant's feedback in 2018 on an Australian policy training course employing the policy cycle: the course offered 'anecdotes that connected theories to real life experiences' (Bridgman \& Malone 2019).

16 For examples of such grey literature see Katsonis (2019), Mainwaring (2019) and Threlfall (2018). 
A common feature of the four theories explored here is that they tend to eschew jargon and complicated presentations of the theory, and to offer evocative images and/or language that provides memorable hooks to cut through and speak to the direct experiences of public servants, as Gilding (this volume, Chapter 11) captures: 'reflecting on my policy successes and failures, there is a correlation with whether the [strategic] triangle is aligned or misaligned'.

For practitioners looking to take theory into the workplace, the approach needs to be readily communicated to other public servants who, in most cases, will not be familiar with the language or underpinning concepts, and who are working in high-stress, rapidly changing circumstances.

From an academic perspective, Howlett, McConnell and Perl (2017, p. 65) describe the value of policy frameworks in terms of their ability to help 'both students and practitioners make sense of the complex set of socio-political activities that constitute policy-making'. Weible and Cairney (2018, p. 186) similarly recognise that, while the complexity of policy processes prevents scholars offering 'precise predictions' for policy actors, scholars nevertheless can:

Help them to make sense of policy theories so that they can think more critically about how they make their choices [in specific instances of policymaking] and how they make sense of their complex context.

Congruent with developing a greater appreciation of complexity, Cairney has also drawn attention to how practitioner-academic discussions can encourage the type of 'intelligent policymaking' promoted by Ian Sanderson, which, at its heart, involves a commitment to experimentation and policy learning (Cairney 2015, p. 33; Sanderson 2009, p. 713).

Employing a lens of 'intelligent policymaking' provides new perspectives into how practitioners apply theory. While there is no simple metric, what we might expect is that a deeper understanding of policy theory could lead to new ways of thinking and/or be employed in critical reflection back in the workplace. From the examples discussed in the previous section, and other chapters in this monograph, we gain some insight into how policy theory has indeed been put to work to enhance practice, including its use as: 
- a 'sense-making tool'when immersed in a policy agenda that can appear chaotic or indeed shambolic

- a policy review framework to reflect on past or current policy episodes, individually or with others, and garner policy learnings

- a means of facilitating conversations through a shared policy vocabulary, even if this may only connect with certain colleagues

- a heuristic or broad guide for leaders to employ individually or with their teams for more strategic policy development processes.

These can occur not only at an individual level, but also at the institutional level, as Maurer (this volume, Chapter 12) demonstrates with the policy handbook that he developed for his department.

We also gain a sense of how policy theory is modified in light of the particular circumstances and institutional culture in which public servants operate. A common thread among the cited examples of practitioners (current and former) is their readiness to adapt theory to their particular environments. Indeed, Ayres in Chapter 8 (this volume) (and it would seem Gilding in Chapter 11), have grafted complexity onto a cycle model in order to create the 'sense-making tool' that policy theorists describe. Presumably, this is the type of professional growth that the authors of the Australian policy handbook suggest is likely to occur with experience and confidence (Althaus, Bridgman \& Davis 2018, p. 5).

While we have Australian examples of theory tested empirically, such as case studies drawing on the MSA, we have no examples of practice directly informing theory, notwithstanding that academics acknowledge that practice can be 'a great stimulant of good theory' (Hartley et al. 2017, p. 671). Improving knowledge exchange between the policy and academic worlds exercises those on both sides (Sullivan 2019, p. 319). Yet, being frank in an academic environment as to how they apply theory in practice may be daunting for practitioners, even for pracademics. The former practitioners who constructed the APC have needed 'broad shoulders' given ongoing academic disparagement. It was also perhaps inevitable that Edwards's employment of a modified policy cycle in her book on social policy case studies would be critiqued by academics (e.g. Gill \& Colebatch 2006, pp. 243-4) for what they saw as tensions between the theory and Edwards's account of her own experience, demonstrating 'the limitations of the model'. Reflecting the trenchant debate over public 
value, Gilding (Chapter 11), in her contribution to this volume, is careful to note that the strategic triangle 'has caused disagreement between public managers and academics'.

From the perspective of practitioners, insights can be gleaned from multiple theories notwithstanding what may appear to be arcane academic disputes. Indeed, in an initiative to move beyond these longstanding debates, Howlett, McConnell and Perl (2017, pp. 67-9) have proposed a new 'five streams framework of the policy process', which would synthesise the strengths in three of the key meta-frameworks: the policy cycle and MSA discussed in this chapter, and also the advocacy coalition framework proposed by Sabatier.

At present, we only have tantalising glimpses into how existing policy theory has been put to work and tested for its relevance and utility in practice. While government support for ANZSOG has helped to expose considerable numbers of Commonwealth, state and New Zealand senior executives to policy theory such as public value, largely it has been left to individuals to bring their learnings back to their workplaces. A practitioner-academic partnership could further our understanding of how this occurs, including any cultural dissonance, through a welldesigned research project or projects to extend our understanding of theory-influenced practice (and vice versa):

- by tapping into public servants' knowledge and application of policy theory, including inchoate understandings of 'policy'

- by investigating what policy theory is offered, particularly in postgraduate public policy offerings, and what resonates with practitioners.

However, this begs the question of the APS's appetite, particularly at senior levels, to recognise that training in policy theory, delivered in an interactive environment, can support the skills development of policy advisers. Apart from the initiative of individuals, we have only uncovered the occasional adoption at particular times by particular institutions of a policy theory or framework. Yet, as highlighted in this book's first chapter, the policy capacity of federal public servants has been in the spotlight again with the independent review of the APS (PM\&C 2019b). In the Coalition government's response to the independent review's final report, the strong message conveyed by Prime Minister Morrison was 
that government 'sets the policy direction' for the nation and the APS delivers through implementation (PM\&C 2019a, p. 9). Only 15 of the 40 recommendations were accepted in full.

Notwithstanding this lukewarm response, the review's recommendation for a new 'professions model' aimed at deepening capacity and expertise has been accepted and APS Commissioner Peter Woolcott has already begun work on this, focusing on human resources, data, digital and procurement areas (PM\&C 2019b, p. 20; Jenkins 2019). In the UK, 28 professions have been established in the Civil Service, and the 'policy profession' has its own professional standards and learning curriculum, with externally accredited courses including masters in public policy (PM\&C 2019b, p. 194; Policy Profession Board 2019). We wait to see whether this international model and others, such as New Zealand's public service 'policy profession', will influence the development of a policy 'standard' for the APS that recognises the value of practitioner-academic interaction.

\section{References}

Adams, D, Colebatch, HK \& Walker, CK 2015, 'Learning about learning: Discovering the work of policy', Australian Journal of Public Administration, vol. 74, no. 2, pp. 101-11, doi.org/10.1111/1467-8500.12119.

Advisory Group on Reform of Australian Government Administration 2010, Ahead of the game: Blueprint for the reform of Australian government administration, Department of the Prime Minister and Cabinet, Canberra, ACT.

Alford, J 2008, 'The limits to traditional public administration, or rescuing public value from misrepresentation', Australian Journal of Public Administration, vol. 67, no. 3, pp. 357-66, doi.org/10.1111/j.1467-8500.2008.00593.x.

Alford, J, Douglas, S, Geuijen, K \& 't Hart, P 2017, 'Ventures in public value management: Introduction to the symposium', Public Management Review, vol. 19, no. 5, pp. 589-604, doi.org/10.1080/14719037.2016.1192160.

Alford, J \& Head, BW 2017, 'Wicked and less wicked problems: A typology and a contingency framework', Policy and Society, vol. 36, no. 3, pp. 397-413, doi.org/10.1080/14494035.2017.1361634. 
Alford, J \& O’Flynn, J 2009, 'Making sense of public value: Concepts, critiques and emergent meanings'. International Journal of Public Administration, vol. 32, nos 3-4, pp. 171-91, doi.org/10.1080/01900690902732731.

Allen, P \& Wanna, J 2016, 'Developing leadership and building executive capacity in the Australian public services for better governance', in A Podger \& J Wanna (eds), Sharpening the sword of state: Building executive capacities in the public services of the Asia-Pacific, ANU Press, Canberra, ACT, doi.org/ 10.22459/SSS.11.2016.02.

Alpers, P \& Ghazman, Z 2019, “The "perfect storm” of gun control: From policy inertia to world leader', in J Luetjens, M Mintrom \& P 't Hart (eds), Successful public policy: Lessons from Australia and New Zealand, ANU Press, Canberra, ACT, doi.org/10.22459/SPP.2019.09.

Althaus, C, Bridgman, P \& Davis, G 2004, The Australian policy handbook: A practical guide to the policy-making process, 3rd edn, Allen \& Unwin, Crows Nest, NSW.

Althaus, C, Bridgman, P \& Davis, G 2013, The Australian policy handbook: A practical guide to the policy-making process, 5th edn, Allen \& Unwin, Crows Nest, NSW.

Althaus, C, Bridgman, P \& Davis, G 2015, 'Learning about learning: Discovering the work of policy', Australian Journal of Public Administration, vol. 74, no. 2, pp. 112-13, doi.org/10.1111/1467-8500.12145.

Althaus, C, Bridgman, P \& Davis, G 2018, The Australian policy handbook: A practical guide to the policy-making process, 6th edn, Allen \& Unwin, Crows Nest, NSW.

Australia and New Zealand School of Government (ANZSOG) 2018, 'Public value or profits? Why I chose a career in the public sector', ANZSOG News, 12 February, www.anzsog.edu.au/resource-library/newsmedia/andrew-nicholls.

Australian Government 2019, APS policy capability roadmap: A practical plan to lift policy capability across the APS, viewed 5 February 2020, www.policyhub. gov.au/sites/default/files/projects/aps-policy-capability-roadmap.pdf.

Banks, G 2018, 'Whatever happened to "evidence based policy making?"', presentation delivered at Alf Rattigan Lecture, Canberra, ACT.

Bardach, E 2009, A practical guide for policy analysis, CQ Press, Washington, DC. 
Benington, J 2009, 'Creating the public in order to create public value?', International Journal of Public Administration, vol. 32, nos 3-4, pp. 232-49, doi.org/10.1080/01900690902749578.

Bridgman, P \& Malone, N 2019, Policy skills, viewed 5 February 2020, www.policy skills.com.au.

Brown, P, Cherney, L, Warner, S, Abazie, UC, Ball, S, Cunningham, LE, Le, LLD, Simpson Reeves, L \& Worsoe, H 2019, Understanding public value workshop: Report on proceedings, University of Queensland, viewed 5 February 2020, apo.org.au/node/252741.

Bryson, JM, Crosby, BC \& Bloomberg, L 2014, 'Public value governance: Moving beyond traditional public administration and the new public management', Public Administration Review, vol. 74, no. 4, pp. 445-56, doi.org/10.1111/ puar. 12238.

Burton, T 2017, 'Canberra clones itself', Mandarin, 8 September, viewed 5 February 2020, webarchive.nla.gov.au/awa/20180313181456/https://www. themandarin.com.au/83422-tom-burton-canberra-clones/.

Cairney, P 2015, 'How can policy theory have an impact on policymaking? The role of theory-led academic-practitioner discussions', Teaching Public Administration, vol.33, no. 1, pp.22-39, doi.org/10.1177/0144739414532284.

Cairney, P \& Jones, MD 2016, 'Kingdon's multiple streams approach: What is the empirical impact of this universal theory?', Policy Studies Journal, vol. 44, no. 1, pp. 37-58, doi.org/10.1111/psj.12111.

Christensen, T \& Lægreid, P 2001, 'A transformative perspective on administrative reforms', in T Christensen \& P Lægreid (eds), New public management: The transformation of ideas and practices, Ashgate, Aldershot, UK.

Cockfield, G \& Botterill, LC 2013, 'Rural and regional policy: A case of punctuated incrementalism?', Australian Journal of Public Administration, vol. 72, no. 2, pp. 129-42, doi.org/10.1111/1467-8500.12016.

Cohen, M, March, J \& Olsen, J 1972, 'A garbage can model of organisational choice', Administrative Science Quarterly, vol. 17, no. 1, pp. 1-25, doi.org/ $10.2307 / 2392088$.

Colebatch, HK 2006, Beyond the policy cycle: The policy process in Australia, Allen \& Unwin, Sydney, NSW.

Crowley, K \& Head, B 2015, 'Policy analysis in Australia: Context, themes and challenges', in B Head \& K Crowley (eds), Policy analysis in Australia, Policy Press, Bristol, UK, doi.org/10.1332/policypress/9781447310273.003.0001. 
Department of Industry, Innovation and Science 2014, Policy development toolkit, internal document, Canberra, ACT.

Department of the Prime Minister and Cabinet (PM\&C) 2019a, Delivering for Australians, viewed 5 February 2020, pmc.gov.au/resource-centre/ government/delivering-for-australians.

Department of the Prime Minister and Cabinet (PM\&C) 2019b, Our public service, our future. Independent review of the Australian Public Service, viewed 5 February 2020, pmc.gov.au/sites/default/files/publications/independentreview-aps.pdf.

Department of Social Services (DSS) 2015, Social policy capability plan, internal document, Canberra, ACT.

Di Francesco, M 2015, 'Policy analysis instruction in Australia', in B Head \& K Crowley (eds), Policy analysis in Australia, Policy Press, Bristol, UK, doi.org/10.1332/policypress/9781447310273.003.0017.

Edwards, M 2001, Social policy, public policy: From problem to practice, Allen \& Unwin, Crows Nest, NSW.

Edwards, MG, Soo, C \& Greckhamer, T 2016, 'Public value management: A case study of transitional change in disability sector reform in Western Australia', Australian Journal of Public Administration, vol. 75, no. 2, pp. 176-90, doi.org/ 10.1111/1467-8500.12193.

Fawcett, P, Jensen, M, Ransan-Cooper, H \& Duus, S 2018, 'Explaining the "ebb and flow" of the problem stream: Frame conflicts over the future of coal seam gas ("fracking") in Australia', Journal of Public Policy, vol. 39, no. 3, pp. 521-41, doi.org/10.1017/S0143814X18000132.

Gallop, G 2018, 'Empowering our senior public servants with political skills', Mandarin, 14 December, viewed 5 February 2020, www.themandarin.com. $\mathrm{au} / 102310$-empowering-our-senior-public-servants-with-political-skills/.

Gill, Z \& Colebatch, HK 2006, “'Busy little workers”: Policy workers' own accounts', in HK Colebatch (ed.), Beyond the policy cycle: The policy process in Australia, Allen \& Unwin, Crows Nest, NSW.

Halton, J 2016, 'Secretary valedictory', in IPAA, Twelve speeches 2016: A year of speeches from public service leaders, IPAA, Canberra, ACT.

Hartley, J, Alford, J, Knies, E \& Douglas, S 2017, 'Towards an empirical research agenda for public value theory', Public Management Review, vol. 19, no. 5, pp. 670-85, doi.org/10.1080/14719037.2016.1192166. 
Howlett, M, McConnell, A \& Perl, A 2017, 'Moving policy theory forward: Connecting multiple stream and advocacy coalition frameworks to policy cycle models of analysis', Australian Journal of Public Administration, vol. 76, no. 1, pp. 65-79, doi.org/10.1111/1467-8500.12191.

IPAA 2018, Future leaders series, ACT Division, 22 November, viewed 5 February 2020, www.act.ipaa.org.au/futureleaders-1.

IPAA 2019, Prioritising reform, ACT Division, 18 September, viewed 5 February 2020, www.act.ipaa.org.au/2019-pastevent-prioritisingreform.

Jenkins, S 2019, 'This APS review will be different, says Commissioner Peter Woolcott', Mandarin, 26 September, viewed 5 February 2020, www.themandarin.com.au/116772-this-aps-review-will-be-different-sayscommissioner/.

Katsonis, M 2019, 'Putting value creation back into public value', Mandarin, 8 July, viewed 5 February 2020, www.themandarin.com.au/111206-valuecreation/.

Kingdon, JW 2011, Agendas, alternatives, and public policies, 2nd edn, Longman, Crawfordsville, IN.

Lancaster, K, Ritter, A, Hughes, C \& Hoppe, R 2017, 'A critical examination of the introduction of drug detection dogs for policing of illicit drugs in New South Wales, Australia using Kingdon's “multiple streams' heuristic”, Evidence and Policy, vol. 13, no. 4, pp. 583-603, doi.org/10.1332/1744264 $16 X 14683497019265$.

Lindblom, CE 1979, 'Still muddling, not yet through', Public Administration Review, vol. 39, no. 6, pp. 517-26, doi.org/10.2307/976178.

Lindquist, E \& Tiernan, A 2011, 'The Australian Public Service and policy advising: Meeting the challenges of 21st century governance', Australian Journal of Public Administration, vol. 70, no. 4, pp. 437-50, doi.org/10.1111/ j.1467-8500.2011.00743.x.

Mackie, K 2016, 'Success and failure in environment policy: The role of policy officials', Australian Journal of Public Administration, vol. 75, no. 3, pp. 291304, doi.org/10.1111/1467-8500.12170.

Maddison, S \& Denniss, R 2009, An introduction to Australian public policy: Theory and practice, Cambridge University Press, Cambridge, UK, doi. org/10.1017/CBO9781139168656. 
Mainwaring, R2019, 'What will the Turnbull-Morrison government be remembered for?' Conversation, 8 April, viewed 5 February 2020, theconversation.com/ what-will-the-turnbull-morrison-government-be-remembered-for-114618.

Moore, MH 1995, Creating public value: Strategic management in government, Harvard University Press, Cambridge, MA.

Moore, MH 2013, Recognizing public value, Harvard University Press, Cambridge, MA, doi.org/10.4159/harvard.9780674067820.

Podger, A 2012, 'My fortunate career and some parting remarks', in J Wanna, $S$ Vincent \& A Podger (eds), With the benefit of hindsight: Valedictory reflections from departmental secretaries, 2004-11, ANU Press, Canberra, doi.org/ 10.22459/WBH.04.2012.02.

Policy Profession Board 2019, 'Looking back to look forward: From "twelve actions" to "policy profession 2025", Mandarin, 2 June, viewed 5 February 2020, www.themandarin.com.au/people/sir-chris-wormald/.

Prebble, M 2012, 'Public value and the ideal state: Rescuing public value from ambiguity', Australian Journal of Public Administration, vol. 71, no. 4, pp. 392-402, doi.org/10.1111/j.1467-8500.2012.00787.x.

Rhodes, RAW 2016, 'Recovering the craft of public administration', Public Administration Review, vol. 76, no. 4, pp. 638-47, doi.org/10.1111/puar. 12504.

Rhodes, RA \& Wanna, J 2007, 'The limits to public value, or rescuing responsible government from the platonic guardians', Australian Journal of Public Administration, vol. 66, no. 4, pp. 406-21, doi.org/10.1111/j.1467-8500. 2007.00553.x.

Rhodes, RA \& Wanna, J 2008, 'Stairways to heaven: A reply to Alford', Australian Journal of Public Administration, vol. 67, no. 3, pp. 367-70, doi.org/10.1111/ j.1467-8500.2008.00594.x.

Rhodes, RA \& Wanna, J 2009, 'Bringing the politics back in: Public value in Westminster parliamentary government', Public Administration, vol. 87, no. 2, pp. 161-83, doi.org/10.1111/j.1467-9299.2009.01763.x.

Rodwell, G 2016 'Re-examining the curriculum development centre: Coordinative federalism and Kingdon's agenda-setting (1975-87)', Education Research and Perspectives, vol. 43, pp. 1-35.

Sanderson, I 2009, 'Intelligent policy making for a complex world: Pragmatism, evidence and learning', Political Studies, vol. 57, no. 4, pp. 699-719, doi.org/ 10.1111/j.1467-9248.2009.00791.x. 
Scott, C \& Baehler, K 2010, Adding value to policy analysis and advice, UNSW Press, Sydney, NSW.

Shergold, P 2015a, 'Foreword', in B Head \& K Crowley (eds), Policy analysis in Australia, Policy Press, Bristol, UK.

Shergold, P 2015b, Learning from failure: Why large government policy initiatives have gone so badly wrong in the past and how the chances of success in the future can be improved, Australian Public Service Commission, Canberra, ACT.

Smith, H 2018, 'Doing policy differently: Challenges and insights', in IPAA, IPAA Speeches 2018: a year of public sector speeches, IPAA, Barton, ACT.

Sullivan, H 2019, 'Building a knowledge-sharing system: Innovation, replication, co-production and trust-a response', Australian Journal of Public Administration, vol. 78, no. 2, pp. 319-21, doi.org/10.1111/1467-8500. 12370 .

Threlfall, D 2018, 'From walk to talk: Academics and practitioners join forces for public policy learning', Mandarin, 10 September, viewed 5 February 2020, www.themandarin.com.au/98387-from-walk-to-talk-academics-andpractitioners-join-forces-for-public-policy-learning/.

Tiernan, A 2011, 'Advising Australian federal governments: Assessing the evolving capacity and role of the Australian Public Service', Australian Journal of Public Administration, vol. 70, no. 4, pp. 335-46, doi.org/10.1111/j.14678500.2011.00742.x.

Varghese, P 2016, 'Parting reflections', in IPAA, Twelve speeches 2016: A year of speeches from public service leaders, IPAA, Canberra, ACT.

Wanna, J, Butcher, J \& Freyens, J 2010, Policy in action: The challenge of service delivery, UNSW Press, Sydney, NSW.

Weible, CM \& Cairney, P 2018, 'Practical lessons from policy theories', Policy and Politics, vol. 46, no. 2, pp. 183-97, doi.org/10.1332/03055731 8X15230059147191.

Weller, PM, Bakvis, H \& Rhodes, RAW (eds) 1997, The hollow crown: Countervailing trends in core executives, Macmillan Press, New York, NY, doi.org/10.1007/9781-349-25870-3.

World Bank 2019, World Bank projectcycle, viewed 16 August 2019, projects.world bank.org/en/projects-operations/products-and-services/brief/projectcycle. 
This text is taken from Learning Policy, Doing Policy: Interactions Between Public Policy Theory, Practice and Teaching, edited by Trish Mercer, Russell Ayres, Brian Head and John Wanna, published 2021 by ANU Press, The Australian National University, Canberra, Australia.

doi.org/10.22459/LPDP.2021.03 